\title{
Hubungan Pengetahuan Ibu Post Partum tentang Manfaat Kolostrum dengan Pemberian Kolostrum pada Bayi Baru Lahir
}

\author{
Kustini $^{1}$ \\ ${ }^{1}$ Universitas Islam Lamongan \\ Corresponding author: Kustini (custiniwil@gmail.com) \\ Received 19 September 2018; Accepted 20 September 2018; Published 24 September 2018
}

\begin{abstract}
The knowledge of post partum mothers about the benefits of colostrum is very important. Colostrum is the best nutrition for babies because the composition of nutrients in it is optimally able to guarantee the growth of the baby's body. The quality of nutrients is also best because it is easily absorbed and digested by the baby's intestines.This type of research is analytic with cross sectional approach. The number of population in this study is the population of post partum mothers as many as 30 post partum mothers. a sample of 28 post partum mothers, taken by simple random sampling. The independent variable is the knowledge of post partum mothers about the benefits of colostrum, while the dependent variable is the administration of colostrum in newborns.From the results of the study data obtained 21 respondents $(75.0 \%)$ of respondents who gave colostrum to their babies and the average mother who had good knowledge of 20 respondents (71.4\%) then carried out the calculation of the statistical value of contingency coefficients obtained $\mathrm{C}=0.609 \mathrm{C}=0.000$ values The $\mathrm{C}$ table is then compared with the value of $\mathrm{p}<0.05$, the result Ho is rejected. Therefore postpartum mothers should give first breast milk or colostrum as early as possible to the baby. and it is expected that midwives as health workers conduct continuous counseling about the benefits of colostrum to post partum mothers.
\end{abstract}

Keywords: Knowledge, benefits of colostrum, giving colostrum

Copyright @ 2018 STIKes Surya Mitra Husada

All rights reserved.

This is an open-acces article distributed under the terms of the Creative Commons Attribution-ShareAlike 4.0 International License.

PENDAHULUAN

ASI (Air Susu Ibu) sebagai gizi terbaik bagi bayi karena komposisi zat- zat gizi di dalamnya secara optimal mampu menjamin pertumbuhan tubuh bayi. Kualitas zat gizinya juga terbaik karena mudah diserap dan dicerna oleh usus bayi. Sehingga penggunaan Air Susu Ibu (ASI) di Indonesia perlu ditingkatkan dan dilestarikan. Dalam "Pelestarian Penggunaan ASI", yang perlu ditingkatkan adalah pemberian asi eksklusif, yaitu pemberian ASI ( Kolostrum) segera setelah bayi lahir sampai umur 6 bulan. Berdasarkan pengamatan peneliti bahwa semakin banyak ibu di zaman sekarang ini 
tidak memberikan ASI eksklusif / kolostrum kepada bayinya. Dan yang mempengaruhi pola menyusui pada masyarakat salah satu diantaranya adalah aspek sosial budaya Pendidikan, Pengetahuan. Sebagaimana yang dikemukakan bahwa salah satu faktor yang mempengaruhi kesehatan masyarakat sangat tergantung pada Pengetahuan, termasuk Pengetahuan Ibu. (Rahayu, 2010)

Menurut Survey Kesehatan Daerah (2013),Angka kematian Bayi (AKB) sebesar 116 per 100.000 kelahiran hidup. Sedangkan menurut Survey Kesehatan Daerah AKB Provinsi Jawa Timur tahun 2005 sebesar 23,71 per 1.000 kelahiran hidup, terjadi kenaikan bila dibanding AKB tahun 2004 sebesar 14,23 per 1.000 kelahiran hidup . Untuk menurunkan AKB salah satunya dengan memberikan kolostrum. Kolostrum mempunyai khasiat untuk membersihkan mekonium sehingga mukosa usus bayi yang baru lahir segera bersih dan siap menerima ASI. Kolostrum mengandung protein, zat penangkal infeksi, mineral (terutama $\mathrm{K}, \mathrm{Na}$ dan $\mathrm{Cl}$ ) dan vitamin yang larut dalam lemak (A,D,E dan K). Dengan keunggulan yang dimiliki kolostrum, cukup jelas bahwa bayi yang memperoleh ASI sedini mungkin (30 menit sesudah lahir) akan terhindar dari kemungkinan terjadinya gangguan pencernaan, infeksi usus dan penyakit lainnya (Rosita, 2008). Setelah di lakukan survey awal pada bulan Januari- Februari 2018 Di Polindes Desa karangwedoro Kec Turi Kab Lamongan terdapat 12 ibu post partum pada semua jenis persalinan dengan bayi lahir hidup. 4 orang post partum memberikan kolostrumnya pada hari pertama setelah melahirkan, dan 8 orang $(66,67 \%)$ post partum membuang kolostrumnya setelah melahirkan, kemudian memberikan ASi pada bayinya setelah hari ke tiga melahirkan.

Beberapa penelitian melaporkan faktor-faktor yang mempengaruhi awal pemberian Kolostrum yaitu petugas kesehatan, psikologi ibu yaitu kepribadian dan pengalaman ibu, sosiobudaya, tata laksana rumah sakit, kesehatan ibu dan anak, pengetahuan ibu mengenai Manfaat Kolostrum, lingkungan keluarga, peraturan pemasaran pengganti ASI dan jumlah anak. (Dwi Hapsari, 2010) Faktor-faktor tersebut diteliti dalam data SDKI 1997 yang melaporkan bahwa hanya 8,3\% yang disusui dalam satu jam pertama setelah lahir dari 52,7\% yang disusui dalam 24 jam pertama. (Dwi Hapsari, 2010).

Melihat kasus diatas maka seorang bidan harus meningkatkan pengetahuan ibu post partum dengan cara memberikan konseling pada ibu tentang bagaimana pentingnya ASI bagi bayi ( anak nya) sejak ibu hamil. Dan mengajarkan ibu untuk melakukan perawatan payudara agar ASI bisa keluar lancar dan bayi nya juga bisa menerima ASI dengan baik. Dan dilakukan IMD ( Inisiasi Menyusu Dini segera setelah lahir agar kolostrum tidak terbuang. (Kartika,2008).

\section{METODE}

Desain penelitian ini adalah penelitian analitik dengan Studi Korelasional, yaitu suatu penelitian yang mengkaji hubungan antara variabel. Peneliti dapat mencari, menjelaskan suatu hubungan, memperkirakan, menguji berdasarkan teori yang ada. Sedangkan bentuk penekanan hubungannya menggunakan cross sectional dimana jenis penelitian yang menekankan pada waktu pengukuran atau observasi data variabel independen dan dependen hanya satu kali pada satu saat, jadi tidak ada follow up (Nursalam, 2008). Dengan demikian desain dalam penelitian ini adalah mengetahui hubungan pengetahuan ibu post partum tentang manfaat kolostrum dengan pemberian kolostrum pada bayi baru lahir. Teknik sampling pada penelitian ini menggunakan simple random sampling yaitu suatu teknik pemilihan sampel dengan setiap elemen diseleksi secara random / acak (Nursalam, 2013). Dengan cara yaitu penyusunan daftar populasi, menghitung besar sampel di wilayah kerja, membuat nomor undian, menggambil undian sebanyak hasil perhitungan sampel. Sampel dalam penelitian ini adalah ibu post partum Di Polindes Desa karangwedoro Kec Turi Kab Lamongan yang memenuhi criteria inklusi dan eksklusi sebanyak 28 Responden. Pada penelitian variabel independennya adalah manfaat kolostrum pada bayi baru lahi sedangkan Variabel tergantung pada penelitian ini adalah pemberian kolostrum pada bayi baru lahir. Mengingat penelitian ini bertujuan untuk hubungan antara variabel independent dengan variabel dependent yaitu Hubungan pengetahuan ibu post partum tentang manfaat kolostrum dengan pemberian kolostrum pada bayi baru lahir. variabel independent skala datanya Ordinal, variabel dependent skala datanya Nominal maka analisa data digunakan adalah uji keifisien kontingensi dengan tingkat kemaknaan dalam penelitian ini 
adalah $\mathrm{p} \leq 0,05$ artinya bila nilai $\mathrm{p} \leq 0,05$ maka $\mathrm{H}_{0}$ ditolak berarti ada singnifikan atau hubungan yang bermakna antara variabel yang diukur.

\section{HASIL DAN PEMBAHASAN}

\section{Analisa Hasil Penelitian}

variabel pengetahuan dlam penelitian ini dikategorikan menjadi tiga, yaitu baik, Cukup dan kurang yang disajikan dalam tabel 1

Tabel 1Distribusi Ibu Post Partum berdasarkan pengetahuan ibu post partum tentang manfaat kolostrum di Polindes Desa karangwedoro Kec Turi Kab Lamongan pada bulan MeiJuni 2018

\begin{tabular}{clccc}
\hline No. & Pengetahuan ibu post partum tentang Manfaat kolostrum & Frekuensi & $\%$ \\
\hline 1. & Kurang & 3 & 10,7 \\
2. & Cukup & 5 & 17,9 \\
3. & Baik & 20 & 71,4 \\
\hline & & 28 & 100 \\
\hline
\end{tabular}

Dari tabel $1 \mathrm{di}$ atas diketahui sebagian besar ibu post partum mempunyai pengetahuan ibu post partum tentang manfaat kolostrum yang baik yaitu 20 orang $(71,4 \%)$ ibu post partum dan sebagian mempunyai pengetahuan ibu post partum tentang manfaat kolostrum yang cukup yaitu 5 orang $(17,9 \%)$ ibu post partum serta sebagian mempunyai pengetahuan ibu post partum tentang manfaat kolostrum yang kurang yaitu 3 orang $(10,7 \%)$ ibu post partum.

Variabel pemberian kolostrum pada bayi baru lahir dikategorikan menjadi dua, yaitu memberikan dan tidak memberikan, disajikan dalam tabel 2.

Tabel 2 Distribusi Ibu Post Partum berdasarkan pemberian kolostrum pada bayi baru lahir di Polindes Desa karangwedoro Kec Turi Kab Lamongan pada bulan Mei-Juni 2018

\begin{tabular}{clccc}
\hline No. & Pemberian kolostrum pada bayi baru lahir & Frekuensi & $\%$ \\
\hline 1. & Memberikan & & 21 & 75 \\
2. & Tidak memberikan & Total & 7 & 25 \\
\hline & & 28 & 100 \\
\hline
\end{tabular}

Dari tabel 2 di atas diketahui sebagian besar ibu post partum memberikan kolostrumnya yaitu 21 orang $(75 \%)$ ibu post partum dan sebagian kecil tidak memberikan kolostrumnya yaitu 7 orang $(25 \%)$ ibu post partum.

Setelah dilakukan analisis univariat pada masing masing variabel, dilakukan analisis bivariat untuk mengetahui hubungan antar variabel. Hubungan pengetahuan ibu post partum tentang manfaat kolostrum dengan pemberian kolostrum pada Bayi Baru Lahir disajikan dalam tabel 3.

Tabel 3 Hubungan pengetahuan ibu post partum tentang manfaat kolostrum dengan pemberian kolostrum pada Bayi Baru Lahir Di Polindes Desa karangwedoro Kec Turi Kab Lamongan pada bulan Mei-Juni 2018

\begin{tabular}{ccccc}
\hline & Pengetahuan ibu post & Pemberian kolostrum pada bayi baru lahir & \\
\cline { 3 - 4 } No. & $\begin{array}{c}\text { partum tentang } \\
\text { manfaat kolostrum }\end{array}$ & Memberikan & Tidak memberikan & \\
\hline 1. & Baik & $19(95 \%)$ & $1(5 \%)$ & $20(100 \%)$ \\
2. & cukup & $2(40 \%)$ & $3(60 \%)$ & $5(100 \%)$ \\
3. & Kurang & $0(0 \%)$ & $3(100 \%)$ & $3(100 \%)$ \\
\hline & Jumlah & $7(25 \%)$ & $21(75 \%)$ & $28(100 \%)$ \\
\hline
\end{tabular}


Dari tabel 3 di atas diketahui bahwa dari 28 ibu post partum yang berpengetahuan kurang 0 orang $(0 \%)$ ibu post partum seluruhnya tidak memberikan kolostrumnya.

Dari hasil statistik koefsien kontingensi (c) dengan uji SPSS versi 16.0 dengan hasil nilai $\mathrm{C}=$ $0,609 \mathrm{C}=0.000$ dimana $\mathrm{p}<0,05$ maka Ho ditolak yang berarti terdapat hubungan pengetahuan ibu post partum tentang manfaat kolostrum dengan pemberian kolostrum pada bayi baru lahir.

\section{PEMBAHASAN}

\section{Pengetahuan Ibu Post Partum Tentang Manfaat Kolostrum}

Dari Tabel 1 menunjukkan bahwa dari 28 ibu post partum yang mempunyai pengetahuan ibu post partum tentang manfaat kolostrum yang baik terdapat 20 orang $(71,4 \%)$ ibu post partum dan pengetahuan ibu post partum tentang manfaat kolostrum yang cukup yaitu 5 orang $(17,9 \%)$ ibu post partum dan ibu yang mempunyai pengetahuan ibu post partum tentang manfaat kolostrum yang kurang yaitu 3 orang ( $10.7 \%$ ) ibu post partum.

Hasil penelitian menunjukkan tingkat pengetahuan responden tentang kolostrum adalah tinggi. Hal ini dipengaruhi oleh beberapa Faktor-faktor yang mempengaruhi awal pemberian Kolostrum yaitu petugas kesehatan, psikologi ibu yaitu kepribadian dan pengalaman ibu, sosiobudaya, tata laksana rumah sakit, pendidikan, umur,pekerjaan, kesehatan ibu dan anak, pengetahuan ibu mengenai Manfaat Kolostrum, lingkungan keluarga, peraturan pemasaran pengganti ASI dan jumlah anak (Dwi Hapsari, 2010).

Pendidikan seseorang berpengaruh pada pengetahuannya, di mana semakin tinggi pendidikan seseorang, makin banyak pula pengetahuan yang dimiliki. Sebaliknya, pendidikan yang rendah / kurang akan menghambat perkembangan sikap seseorang terhadap nilai baru yang di perkenalkan sehingga pengetahuan juga kurang. Hal ini terbukti dari hasil penelitian yaitu bahwa tingkat pengetahuan ibu post partum tentang manfaat kolostrum berpengaruh pada pemberian kolostrum pada bayi baru lahir. Dengan tingkat pengetahuan yang rendah lebih berpotensi tidak memberikan kolostrum di bandingkan dengan tingkat pengetahuan yang lebih tinggi.Pengetahuan atau kognitif merupakan domain yang sangat penting untuk terbentuknya tindakan seseorang (overt behavior). Sebelum orang mengadopsi perilaku baru, di dalam diri seseorang tersebut. (Notoatmodjo, 2013)

\section{Pemberian Kolostrum Pada Bayi Baru Lahir}

Tabel 2 menunjukkan bahwa pemberian kolostrum pada bayi baru lahir dari 28 ibu post partum terdapat 21 orang $(75.0 \%)$ ibu post partum yang memberikan kolostrum pada bayinya. Sedangkan 7 orang $(25.0 \%)$ ibu post partum yang tidak memberikan kolostrum pada bayinya. Ditinjau dari pendidikan ibu nifas sebagian besar berpendidikan SMA sebanyak 16 orang $(57,1 \%)$ ibu post partum. Dari hasil tersebut menunjukkan secara umum responden telah memberikan kolostrum pada bayinya. Hal ini didukung dengan pengetahuan ibu post partum yang baik tentang manfaat kolostrum. (Dwi Hapsari, 2010) ada beberapa faktor yang mempengaruhi pemberian kolostrum, antara lain: faktor sosial budaya, faktor petugas kesehatan, psikologi ibu yaitu kepribadian dan pengalaman ibu, sosio-budaya, tata laksana rumah sakit, pendidikan, umur, pekerjaan, kesehatan ibu dan anak, pengetahuan ibu mengenai Manfaat Kolostrum, lingkungan keluarga, peraturan pemasaran pengganti ASI dan jumlah anak.

Petugas kesehatan mempunyai peranan dalam memberikan informasi tentang manfaat kolostrum, Paritas, Seorang ibu dengan bayi pertama mungkin akan mengalami masalah ketika menyusui yang sebetulnya hanya karena tidak tahu cara menyusui yang sebenarnya, serta faktor ekonomis: dengan memberikan kolostrum yang langsung kepada bayi setelah lahir, ibu tidak perlu mengeluarkan biaya sehingga akan menghemat pengeluaran.

Hubungan Pengetahuan Ibu Post Partum Tentang Manfaat Kolostrum Dengan Pemberian Kolosrtum Pada Bayi Baru Lahir Di BPS. Aida Hartatik, Amd. Keb Ds. Dlanggu Kecamatan Deket Kabupaten Lamongan 
Dari tabel 3 hasil uji statistik koefisiensi kontingensi pada tabulasi silang menunjukkan bahwa Ho ditolak yang artinya terdapat hubungan pengetahuan ibu post partum tentang manfaat kolostrum dengan pemberian kolostrum pada bayi baru lahir.

Pengetahuan yang dicakup dalam domain kognitif mencakup 6 tingkatan Tahu (know) Diartikan mengingat suatu materi yang dipelajari termasuk mengingat kembali terhadap suatu yang spesifik dari suatu bahan yang dipelajari atau rangsang yan diterima, Memahami (Comprehension) Diartikan sebagai suatu kemampuan menjelaskan secara benar tentang objek yang diketahui dan dapat menginterpretasikan secara benar, Aplikasi (application) Diartikan sebagai suatu kemampuan untuk menggunakan materi yang dipelajari pada situasi yang nyata, Analisis (analysis) Adalah suatu kemampuan untuk menjabarkan materi atau suatu objek ke dalam komponen - komponen tapi masih dalam satu organisasi tersebut dan masih berkaitan, Sintesis (Synthesis) Menunjukkan pada satu kemampuan untuk meletakkan atau menghubungkan bagian - bagian dalam satu bentuk keseluruhan yang baru, Evaluasi (Evaluation) Berkaitan dengan kemampuan untuk melakukan penilaian terhadap suatu objek. Penilaian ini berdasarkan suatu kriteria sendiri atau menggunakan kriteria-kriteria yang ada. Menurut Jainah (2009) ibu dengan pengetahuan tinggi mempunyai kecenderungan untuk memberikan kolostrum. Hal ini menunjukkan keterkaitan antara pengetahuan tentang kolostrum dengan pemberiannya. Dari tabel terlihat ibu dengan pengetahuan kolostrum yang tinggi mempunyai kecenderungan yang tinggi untuk memberikan kolostrum dibandingkan dengan ibu dengan tingkat pengetahuan yang rendah.

Pengetahuan merupakan domain yang sangat penting untuk terbentuknya tindakan seseorang. Dan tindakan maka akan timbul suatu kesadaran (Awareness), tertarik ( interest), penilaian (evaluation), mencoba (trial), dan adaptasi (Adaption) sehingga akhirnya orang itu mampu mengaplikasikan pengetahuan yang didapat dalam kehidupan yang nyata (Notoatmodjo,2010).

Pemberian kolostrum merupakan perilaku atau tindakan ibu. Dimana tindakan ibu tersebut dipengaruhi oleh pengetahuan tentang manfaat kolostrum. bahwasanya pengetahuan adalah faktor yang sangat penting untuk terbentuknya perilaku atau tindakan untuk merubah perilaku seseorang yang disengaja. Kemudian muncul respons dalam bentuk sikap terhadap obyek yang telah diketahui dan disadari sepenuhnya, selanjutnya dari respon sikap dibentuk perilaku. Berdasarkan pengalaman dan penelitian ternyata perilaku yang didasari oleh pengetahuan akan lebih bertahan lama dari pada perilaku yang tidak didasari oleh pengetahuan.

\section{SIMPULAN}

Ada hubungan pengetahuan ibu post partum tentang manfaat kolostrum dengan pemberian kolostrum pada bayi baru lahir Di Polindes Desa Karangwedoro Kec Turi Kab Lamongan

\section{REFERENSI}

Aziz Alimul Hidayat, A. (2013). Pengantar Kebutuhan Dasar Manusia, Aplikasi dan Proses Keperawatan. Jakarta: Salemba Medika

Azrul, Azwar. (2010). Metodologi Penelitian Kedokteran dan Kesehatan Masyarakat. Yogyakarta: Pustaka Pelajar.

Christine., Henderson., \& Jones, Kethlen. (2015). Buku Ajar Konsep Kebidanan.. Jakarta: EGC.

Deddy, Muchtadi, (2006). Gizi Untuk Bayi, ASI, Susu Formula dan Makanan Tambahan. Jakarta: Penebar Swadaya.

Friedman, Marilyn, M. (2008). Perawatan Keluarga Edisi 3. Jakarta: EGC.

Handrawan, Nadesul, (2015). Makanan Sehat Untuk Bayi.. Jakarta: Puspa Swara.

Krisnatuti. (2010), Dasar-dasar Ilmu Gizi, Jakarta: YBP-SP.

Michael, J. Gibney, etal. (2008). Gizi Kesehatan Masyarakat. Jakarta: EGC. 
Nasrul, Effendy. (2008). Dasar-dasar Keperawatan Mayarakat. Jakarta: EGC.

Notoatmodjo, Soekidjo. (2013). Ilmu Kesehatan Masyarakat. Cetakan pertama. Jakarta: Rineka Cipta.

Notoatmodjo, Soekidjo. (2009). Kesehatan Masyarakat. Jakarta: Rineka Cipta.

Nursalam., \& Siti, Pariani. (2011). Pendekatan Praktis dan Metodologi Riset Keperawatan. Jakarta: Sagung Seto.

Nursalam. (2013). Konsep dan Penerapan Metodologi Penelitian Ilmu Keperawatan. Jakarta: Salemba Medika. Nursalam. (2008). Konsep dan Penerapan Metodologi Penelitian Ilmu Keperawatan. Jakarta: Salemba Medika.

Pudjiadi. (2010). Ilmu Gizi dan Aplikasinya. Jakarta: DPN.

RI., Depkes. (2013). Memilih makanan Seimbang. Jakarta: Depkes RI.

Saifuddin, AB, dkk. (2009). Buku Acuan Nasional Pelayanan Kesehatan Maternal dan Neonatal. Jakarta: YBPSP.

Soekidjo, Notoatmodjo. (2010). Metodologi Penelitian Kesehatan. Cetakan ketiga Jakarta: Rineka Cipta.

Soetjiningsih. (2008). ASI: Petunjuk Untuk Tenaga Kesehatan. Jakarta: EGC.

Sudarwan, Danim. (2013). Metode Penelitian Kebidanan.. Jakarta: EGC.

Sudiharto. (2010). Asuhan Keperawatan Keluarga. Jakarta: EGC.

Suhardjo, W. (1999). Pangan Gizi dan Pertanian. Jakarta: UI Press

Suharsimi, Arikunto. (2009). Prosedur Penelitian Suatu Pendekatan Praktek. Jakarta: Rineka Cipta.

Supartini, Yupi. (2014). Buku Ajar Konsep Dasar Keperawatan Anak. Jakarta: EGC

Suprajitno. (2014). Asuhan Keperawatan Keluarga. Jakarta: EGC.

Tri, Rusmi, Widayatun. (2009). Ilmu Perilaku. Jakarta: EGC.

Utami, Roesli. (2010). Mengenal ASI Eksklusif. Jakarta: EGC

Wahit, Iqbal, Mubarak. (2015). Pengantar Keperawatan Komunitas. Jakarta: Sagung 